УДК 547.992.3

\title{
ДЕПОЛИМЕРИЗАЦИЯ ЛИГНИНА ГИДРОТЕРМАЛЬНЫМ МЕТОДОМ
}

\author{
() С.Г. Ильясов"*, В.А. Черкаиин, Г.В. Сакович \\ Институт проблем химико-энергетических технологий Сибирского \\ отделения Российской академии наук, ул. Социалистическая, 1, Бийск, \\ 659322 (Россия), e-mail: admin@ipcet.ru
}

Методом гидротермальной деполимеризации гидротропного лигнина, полученного из лигноцеллюлозного материала (Miscanthus sinensis Andersson), удалось получить две модифицированные формы лигнина. Одна из них растворяется во многих органических растворителях (органосолв), и имеет температуру размягчения $48-98{ }^{\circ} \mathrm{C}$, а другая форма практически нерастворима в органических растворителях и не подвергается размягчению даже при высоких температурах.

Ключевые слова: гидротропный лигнин, ацетонлигнин, деполимеризация, гидротермообработка, organosolve, Miscanthus sinensis Andersson.

\section{Введение}

На сегодняшний день перспективным видом возобновляемого растительного сырья для получения целлюлозы рассматривается энергетическая культура - мискантус [1-3].

Одним из актуальных вопросов получения целлюлозы является и проблема получения лигнина, обеспечивающего получение жизненно важных и полезных продуктов. В этом аспекте лигнин рассматривается как ингредиент композиционных материалов, например в роли экологического связующего в древесно-стружечных плитах [4].

Уделяется большое внимание процессу гидролиза биомассы (лигноцеллюлозной массы) при высоком давлении. В этом процессе гидролиза используют воду как в докритических, так и в сверхкритических условиях [5, 6]. Гидролиз дает частицы лигнина размером менее 300 нм. Молекулярная масса полученного лигнина приблизительно составляет половину массы лигнина Kraft-процесса и Organosolve-процесса. Лигнин, полученный в условиях высокого давления и выделенный ультрафильтрацией, обладает свойствами термопластичного материала, как Arboform ${ }^{\circledR}[5]$.

В этом аспекте представляет интерес проведение исследований термического гидролиза с индивидуальным образцом лигнина, который бы не содержал примеси целлюлозы, гемицеллюлозы, жирных эфиров и кислот. В качестве такого объекта исследований был выбран образец гидротропного лигнина, полученного по методу, описанному в работе [1].

Преимущество гидротропного способа делигнификации растительного сырья заключается в том, что

Ильясов Сергей Гаврилович - заместитель директора по научной работе, доктор химических наук, тел./факс: (3854) 30-59-37, e-mail: admin@ ipcet.ru Черкашин Виктор Александрович - ведущий инженер, тел.: (3854) 30-14-89, e-mail: vikt12009@yandex.ru Сакович Геннадий Викторович - советник РАН, научный руководитель института, академик РАН, тел.: (3854) 30-59-55, факс (3854) 30-30-43, e-mail: admin@ipcet.ru варка производится с нейтральным раствором $30 \%$ раствора бензоата натрия, а это почти исключает деградацию целлюлозы и приводит к высокому выходу продукта с большим содержанием $\alpha$-целлюлозы. По той же причине выделяемый из растительного сырья лигнин сравнительно мало изменяется и обладает повышенной реакционной способностью [7].

\footnotetext{
* Статья имеет электронный дополнительный материал (приложение): DOI: 10.14258/jcprm.1304021s.

*** Автор, с которым следует вести переписку.
} 


\section{Экспериментальная часть}

ИК-спектры поглощения образцов лигнина в $\mathrm{KBr}$ были получены на ИК-Фурье-спектрофотометре «ФТ-801». Область исследований от 4000 до $500 \mathrm{~cm}^{-1}$. Кристаллический КВr растирали агатовым пестиком в агатовой ступке до тонкого помола (100-30 мкм), в который вводился порошок исследуемых лигнинов, с концентрацией до 1\% (весовых). Микротаблетки (толщина слоя 1-2 мм, диаметр 3,5 мм) изготавливали на ручном прессе фирмы СИМЕКС. Затем таблетку вставляли в держатель, находящийся в кюветном отделении. Съемку спектра вели при закрытой крышке кюветного отделения.

Элементный анализ проведен на элементном анализаторе Flash EA ${ }^{\mathrm{TM}} 1112$ фирмы Thermo Quest.

Термоаналитические исследования проводили в условиях программируемого линейного нагрева на дифференциально-сканирующем калориметре DSC822е/400 и модуле термогравиметрического и дифференциального термического анализа TGA/SDTA851e/LF/1600 фирмы METTLER TOLEDO в политермическом режиме (в атмосфере азота, при скорости нагрева $\left.10{ }^{\circ} \mathrm{C} / \mathrm{Mин}\right)$.

Метоксильные группы анализировали согласно методике [9], с непосредственным получением НI в реакционной смеси: в круглодонную колбу вместимостью 50 мл помещали 50 мг исследуемого вещества, 1 г иодида калия, 2 мл ортофосфорной кислоты, закрывали обратным холодильником и выдерживали на глицериновой бане $\left(150{ }^{\circ} \mathrm{C}\right)$ в течение 15 мин. После охлаждения колбы с продуктами реакции до комнатной температуры через обратный холодильник вносили 10 мл дистиллированной воды, 10 мл четыреххлористого углерода (пипеткой Мора). Затем колбу с обратным холодильником энергично встряхивали в течение 10 мин для экстракции иодистого метила. После отстаивания содержимого колбы пипеткой отбирали нижний органический слой, переносили в делительную воронку с раствором сульфита натрия. Делительную воронку встряхивали до полного обесцвечивания органического слоя. После отстаивания содержимого делительной воронки органический слой сливали в пробирку с безводным сульфатом натрия и закрывали притертой пробкой.

Условия хроматографирования следующие: хроматограф газовый «Кристаллюкс 4000М», детектор пламенно-ионизационный, колонка - Phenomenex с фазой ZB-1 (100\% диметилполисилоксан), длина: 60 м., внутренний диаметр: 0,32 мм, газ-носитель - азот осч., температура колонки $-85^{\circ} \mathrm{C}$, температура детектоpa $-150{ }^{\circ} \mathrm{C}$, температура испарителя $-120^{\circ} \mathrm{C}$, скорость потока газа-носителя -20 мл/мин, объем вводимой пробы - 1 мкл.

Объектом исследования являлся гидротропный лигнин (ГЛ), полученный из мискантуса китайского (Веерник китайский Miscanthus sinensis Andersson), урожая 2008 г., выращенного на плантациях Института цитологии и генетики СО РАН в Новосибирской области [10].

Результаты определения химического состава мискантуса показали содержание целлюлозы по Кюршнеру в пределах 57\% (чистой целлюлозы около 44\%), лигнина - 19,1\%, пентозанов - 23\%, золы - 3,9\%.

Сырье анализировали по стандартным методикам: м.д. золы - методом озоления в муфельной печи Nabertherm [11], м.д. водорастворимых веществ - методом экстрагирования горячей водой [11], м.д. кислотонерастворимого лигнина - сернокислотным методом [11], м.д. целлюлозы по Кюршнеру - азотноспиртовым методом [11], массовую долю пентозанов - спектрофотометрическим методом на приборе UNICO UV-2804 [11]. Результаты определения приведены в пересчете на абсолютно сухое сырье (а.с.с).

Получение гидротропного варочного раствора по методу [1]. В качестве гидротропного раствора на стадии делигнификации использовали $30 \%$ раствор бензоата натрия. Варку измельченного мискантуса проводили в качающемся автоклаве [12] емкостью 4,2 л. Разделение твердой и жидкой фаз после варки и во время промывок, проводили отжимом на механическом прессе.

Предгидролиз. В качающийся автоклав помещают 280 г измельченного растительного сырья и 2,25 л дистиллированной воды (модуль $1: 8$ ). Автоклав герметизируют, включают перемешивание, нагревают до $140{ }^{\circ} \mathrm{C}$ и выдерживают при этой температуре 1 ч. Давление в автоклаве в пределах 2-3 атм. По окончании выдержки автоклав охлаждают до $30-35{ }^{\circ} \mathrm{C}$, лигноцеллюлозу отжимают, промывают дистиллированной водой $40-50{ }^{\circ} \mathrm{C}, 3$ раза по 1 л, затем дистиллированной водой до обесцвечивания промывных вод, после чего высушивают в течение 8 ч при температуре 100-105 ㄷ. Выход лигноцеллюлозы 193,7 г (69,2\%)

Гидротропная делигнификация. В качающийся автоклав помещают 193,7 г лигноцеллюлозы и 2,5 л гидротропного раствора (модуль $1: 15)$. Автоклав герметизируют, включают перемешивание, нагревают до $160 \pm 10^{\circ} \mathrm{C}$ и выдерживают при этой температуре в течение 3 ч. Давление в автоклаве в пределах 
2-3 атм. По окончании выдержки автоклав охлаждают до $30-35{ }^{\circ} \mathrm{C}$, техническую целлюлозу отжимают, промывают однократно 2 л гидротропного раствора $\left(40-50{ }^{\circ} \mathrm{C}\right)$. Получают 4,5 л варочного раствора.

Получение ГЛ из варочного раствора. 1,0 л варочного раствора, полученного после гидротропной варки, нагревают до 50-55 ${ }^{\circ} \mathrm{C}$ и добавляют при перемешивании 2,0 л дистиллированной воды. Перемешивание выключают и выдерживают 1 ч при $50{ }^{\circ} \mathrm{C}$, затем 12 ч при $25{ }^{\circ} \mathrm{C}$. Выпавший осадок отфильтровывают под вакуумом и промывают дистиллированной водой 4 раза по 100 мл, сушат при комнатной температуре до постоянного веса. Получают 7,1 г (59,8\%) гидротропного лигнина. Полученный лигнин представляет собой порошок коричневого цвета, не имеющий температуры размягчения при нагревании до $400{ }^{\circ} \mathrm{C}$, с характеристиками, указанными в таблице 3.

Получение ацетонлигнина (АЛ) из ГЛ. К 150 мл дистиллированной воды присыпают 14,5 г гидротропного лигнина. Суспензию нагревают с обратным холодильником до кипения и выдерживают 5 мин. По окончании выдержки порошок отфильтровывают и высушивают в течение 24 ч при температуре $25{ }^{\circ} \mathrm{C}$. Измельченный порошок растворяют в ацетоне при $25^{\circ} \mathrm{C}$. Ацетоновый раствор фильтруют и испаряют на роторном испарителе в вакууме. Получают 6,2 г (42,76\%) АЛ. Полученный АЛ представляет собой порошок коричневого цвета с характеристиками, указанными в таблице 3.

\section{Обсуждение результатов}

Первый этап исследований посвящен выбору органического растворителя, экстрагента ГЛ.

Навеска ГЛ подвергалась исчерпывающему растворению при $25^{\circ} \mathrm{C}$ в органических растворителях, таких как: ДМФА, ДМСО, ТБФ, уксусная кислот, метанол, этанол, диоксан, ацетон, хлороформ, толуол, диэтиловый эфир, гексан (табл. 1). Из таблицы 1 видно, что ГЛ имеет различную исчерпывающую растворимость в органических растворителях, что, по-видимому, связано с содержанием в составе ГЛ различных молекулярных структур макромолекул.

Нерастворимые остатки (графа 4 табл. 1), отделенные от растворителей под №o 4-12, хорошо растворяются в ДМФА, ДМСО и ТБФ.

В связи с этим исчерпывающее растворение образцов лигнина далее нами рассматривается как процесс селективного экстрагирования одной из модификаций гидротропного лигнина.

В последующих исследованиях в качестве селективного экстрагента при получении органорастворимого лигнина использовался ацетон (исходя из наименования применяемого экстрагента, получаемый продукт назвали созвучно - ацетонлигнином). Это связано с тем, что ацетон не взаимодействует с лигнином, а метанол и этанол являются потенциальными реагентами, способными образовывать простые и сложные эфиры с фрагментами спиртовых и кислотных остатков лигнина в соответствующих условиях, уксусная кислота может выступать как деструктирующий агент. Выбор между ацетоном и диоксаном был сделан в пользу меньшей исчерпывающей растворимости, то есть селективности, 14 и $39 \%$ соответственно (табл. 1). Хлороформ, диэтиловый эфир, толуол и гексан, ввиду малой их растворимости гидротропного лигнина, нами не рассматривались как экстрагенты для дальнейших исследований.

АЛ был подвергнут исчерпывающей экстракции этими же растворителями, с последующим выделением сухого остатка из них, что позволило составить классификационную таблицу экстрагируемости АЛ (табл. 2).

ГЛ был исследован на устойчивость к горячей воде при атмосферном давлении.

Таблица 1. Исчерпывающая растворимость (весовой процент) ГЛ в органических растворителях при $25^{\circ} \mathrm{C}$

\begin{tabular}{c|l|c|c}
\hline № & \multicolumn{1}{|c|}{ Растворитель } & Сухой остаток из экстракта, \% & ${\text { Нерастворимый остаток, } \%^{1}}^{1}$ \\
\hline 1 & ДМСО & 100 & 0 \\
2 & ДМФА & 100 & 0 \\
3 & ТБФ & 100 & 30 \\
4 & Уксусная кислота & 70 & 40 \\
5 & Метанол & 60 & 52 \\
6 & Этанол & 48 & 61 \\
7 & Диоксан & 39 & 86 \\
8 & Ацетон & 14 & 94 \\
9 & Хлороформ & 6 & 99 \\
10 & Диэтиловый эфир & 1 & 99 \\
11 & Толуол & 1 & 100 \\
12 & Гексан & 0 & 0 \\
\hline
\end{tabular}

Примечания: ${ }^{1}$ в расчете на количество, взятое для экстракции; ${ }^{2}$ ТБФ - трибутиловый эфир ортофосфорной кислоты 
Таблица 2. Экстракция АЛ растворителями при $25^{\circ} \mathrm{C}$

\begin{tabular}{l|c|c}
\hline \multicolumn{1}{c|}{ Растворитель } & $\begin{array}{c}\text { Сухой остаток из } \\
\text { экстракта, \% }\end{array}$ & $\begin{array}{c}\text { Нерастворимый } \\
\text { остаток, \% }^{*}\end{array}$ \\
\hline Трибутилфосфат & 100 & 0 \\
ДМСО & 100 & 0 \\
ДМФА & 100 & 0 \\
Уксусная кислота & 100 & 0 \\
Диоксан & 100 & 0 \\
Ацетон & 100 & 0 \\
Метанол & 97 & 3 \\
Этанол & 90 & 10 \\
Хлороформ & 60 & 40 \\
Диэтиловый эфир & 4 & 96 \\
Толуол & 0 & 100 \\
Гексан & 0 & 100 \\
\hline
\end{tabular}

Примечание: * - в расчете на количество, взятое для экстракции.
Гидролиз ГЛ проводили горячей водой при $100{ }^{\circ} \mathrm{C}$ в течение 5-90 мин при атмосферном давлении. Было выявлено, что гидротермальная обработка ГЛ способствует увеличению растворимости ГЛ в ацетоне. Наилучшие результаты (45\%) по извлечению ацетонлигнина из ГЛ получены при кипячении образца в воде в течение 1 ч. Длительное кипячение (до 3 ч) образца ГЛ не способствует увеличению выхода АЛ.

Сравнение результатов элементного анализа показывает, что АЛ содержит меньше кислорода $(26,06 \%)$, чем ГЛ $(31,42 \%)$ и нерастворимый остаток в ацетоне (НОА) (30,25\%) (табл. 3$)$.

Известно [13], что для ацетосолв и формосолв, полученных из Miscanthus x giganteus, содержание метоксильных групп соответствует $\mathrm{C}_{9} \mathrm{H}_{6,87} \mathrm{O}_{2,19}\left(\mathrm{OCH}_{3}\right)_{1,01}$ и $\mathrm{C}_{9} \mathrm{H}_{7,04} \mathrm{O}_{2,64}\left(\mathrm{OCH}_{3}\right)_{0,65}$.

Низкое содержание метоксильных групп $(0,11)$ для АЛ свидетельствует о преимущественном строении ФПЕ Н(Н') - n-оксифенильного звена. В пользу такого предположения свидетельствует то, что в ИКспектре АЛ отсутствуют полосы колебаний на $1330 \mathrm{~cm}^{-1}(\mathrm{~S})$, и ароматические плоскостные колебания на $1126(\mathrm{~S})$ и $1032 \mathrm{~cm}^{-1}(\mathrm{G})$, и внеплоскостное колебания на $916 \mathrm{~cm}^{-1}(\mathrm{G})$ (табл. 4). Идентификацию полос ИКспектров ГЛ, НОА и АЛ проводили в соответствии с литературными данными [14], ближайшего аналога organosolve Miscanthus x giganteus Lignin.

В ИК-спектре образца АЛ содержится интенсивный сигнал полосы колебания в области $1702 \mathrm{~cm}^{-1}$ (рис. 1), характерный для карбонильной группы (табл. 4).

ИК-спектр НОА (рис. 1) сравним с ИК-спектром ГЛ, отличие - отсутствие полосы колебания в области $717 \mathrm{~cm}^{-1}$.

Результаты исследований дифференциально-сканирующей калориметрии и термогравиметрического анализа показывают, что ацетонлигнин имеет температуру начала размягчения $48{ }^{\circ} \mathrm{C}$, максимум поглощения тепла при $84{ }^{\circ} \mathrm{C}$, и конец тепловых процессов при $95{ }^{\circ} \mathrm{C}$ (рис. 2). Повторный нагрев исследуемого образца показывает воспроизводимость результатов измерений температуры размягчения.

Низкая температура размягчения образцов АЛ характеризуется как полезное свойство связующих веществ. В связи с этим АЛ можно рассматривать как ингредиент композиционных материалов в качестве связующего компонента.

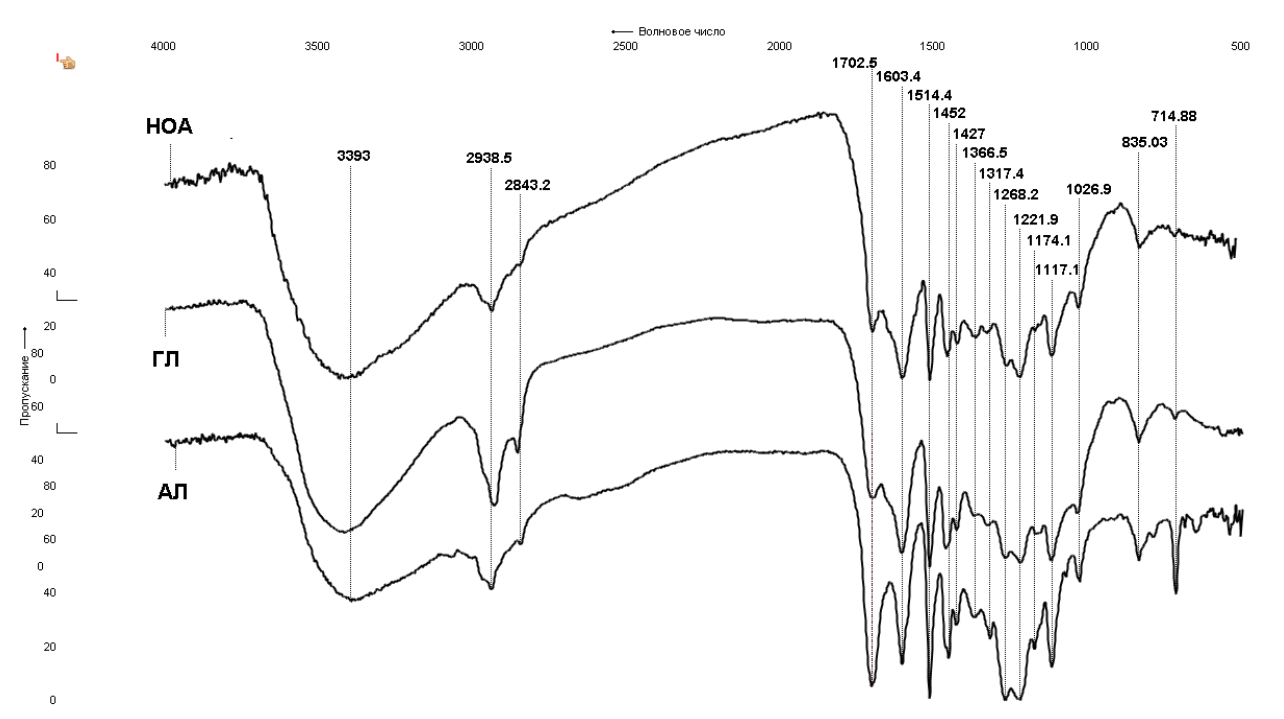

Рис. 1. ИК-спектры АЛ, ГЛ и НОА 
Таблица 3. Данные элементного анализа различных видов лигнинов

\begin{tabular}{|c|c|c|c|c|c|c|}
\hline \multirow{2}{*}{ Наименование } & \multicolumn{3}{|c|}{ Элементный анализ } & \multirow{2}{*}{$\mathrm{OCH}_{3}, \%$} & \multirow{2}{*}{$\begin{array}{c}\text { Зольность, } \\
\%\end{array}$} & \multirow{2}{*}{$\begin{array}{c}\text { Брутто-формула ФПЕ, М вес, а.у.е } \\
\text { (расчет) }\end{array}$} \\
\hline & $\mathrm{C}, \%$ & $\mathrm{H}, \%$ & $\mathrm{O}, \%$ & & & \\
\hline ГЛ & 61,00 & 5,50 & 31,42 & 4,48 & 2,08 & $\mathrm{C}_{9,00} \mathrm{H}_{9,15} \mathrm{O}_{3,31}\left(\mathrm{OCH}_{3}\right)_{0.26}(178,4)$ \\
\hline АЛ & 67,70 & 6,00 & 26,06 & 2,19 & 0,24 & $\mathrm{C}_{9,00} \mathrm{H}_{9,04} \mathrm{O}_{2,52}\left(\mathrm{OCH}_{3}\right)_{0,11}(160,9)$ \\
\hline HOA & 58,10 & 5,40 & 30,25 & 4,48 & 6,25 & $\mathrm{C}_{9,00} \mathrm{H}_{9,11} \mathrm{O}_{3,34}\left(\mathrm{OCH}_{3}\right)_{0,28}(179,3)$ \\
\hline
\end{tabular}

Таблица 4. Данные ИК-спектров различных лигнинов

\begin{tabular}{|c|c|c|c|c|}
\hline Наименование & {$[14]^{*}, \mathrm{~cm}^{-1}$} & ГЛ, $\mathrm{cm}^{-1}$ & $\mathrm{HOA}, \mathrm{cm}^{-1}$ & $\mathrm{~A} Л, \mathrm{~cm}^{-1}$ \\
\hline $\begin{array}{l}\text { C=O валентные колебания в несвязанных кетонах, карбониль- } \\
\text { ных группах и эфирных группах }\end{array}$ & 1725 & - & - & 1702(c.), \\
\hline $\begin{array}{l}\text { C=O валентные колебания в связанных альдегидах и карбоно- } \\
\text { вых кислотах }\end{array}$ & 1695 & 1701(сл.) & 1698(сл.) & - \\
\hline C=O в сопряженных р-замещенных арилзамещенных кетонах & 1636 & - & - & - \\
\hline Скелетные колебания ароматического кольца & 1600 & 1604 & 1604 & 1603 \\
\hline Скелетные колебания ароматического кольца & 1505 & 1514 & 1514 & 1514 \\
\hline $\mathrm{C}-\mathrm{H}$ асимметричные деформационные колебания в $-\mathrm{CH}_{3}$ и $-\mathrm{CH}_{2}-$ & 1460 & 1462 & 1454 & 1452 \\
\hline $\begin{array}{l}\text { Ароматическое скелетное колебание, объединенное с плоско- } \\
\text { стной деформацией C-H }\end{array}$ & 1425 & 1426 & 1424 & 1427 \\
\hline Алифатические C-H в $-\mathrm{CH}_{3}$ & 1370 & 1369 & 1364 & 1366 \\
\hline $\begin{array}{l}\text { Кольца конденсированных S и G (замещенных в одном из } \\
\text { положений в кольце) }\end{array}$ & 1330 & 1326 & 1328 & - \\
\hline Колебание кольца & - & - & - & 1317 \\
\hline «дыхание» кольца G-звена с полосой C=O & 1268 & 1268 & 1267 & 1268 \\
\hline $\mathrm{C}-\mathrm{C}, \mathrm{C}-\mathrm{O}$ и $\mathrm{C}=\mathrm{O}$ полоса & 1226 & 1219 & 1221 & 1221 \\
\hline C-O в сложных эфирных группах & 1166 & 1169 & - & 1174 \\
\hline $\begin{array}{l}\text { Ароматическая C-H внугриплоскостная деформация, характер- } \\
\text { ная для S-звена }\end{array}$ & 1126 & - & 1122 & - \\
\hline Ароматическая C-H & - & 1119 & - & 1117 \\
\hline C-O деформация во вторичных спиртах и алифатических эфирах & 1086 & - & - & - \\
\hline $\begin{array}{l}\text { Ароматическая C-Н внутриплоскостная деформация, G > S; } \\
\mathrm{C}-\mathrm{O} \text { деформация в первичных спиртах }\end{array}$ & 1032 & 1035 & 1035 & - \\
\hline Ароматическая $\mathrm{C}-\mathrm{H}$ & - & - & - & 1026 \\
\hline C-H внеплоскостное в положении 2, 5, и 6 G-звена & 870 & - & - & - \\
\hline $\begin{array}{l}\text { C-Н внеплоскостное в положении } 2 \text {, и } 6 \text { S-звена и во всех по- } \\
\text { ложениях для Н-звена }\end{array}$ & 835 & 835 & 832 & 835 \\
\hline C-Н внеплоскостное во всех положениях для Н-звена & - & 717 & - & 715 \\
\hline
\end{tabular}

Примечание: с. - сильная, сл. - слабая, * ИК-спектр сравнения

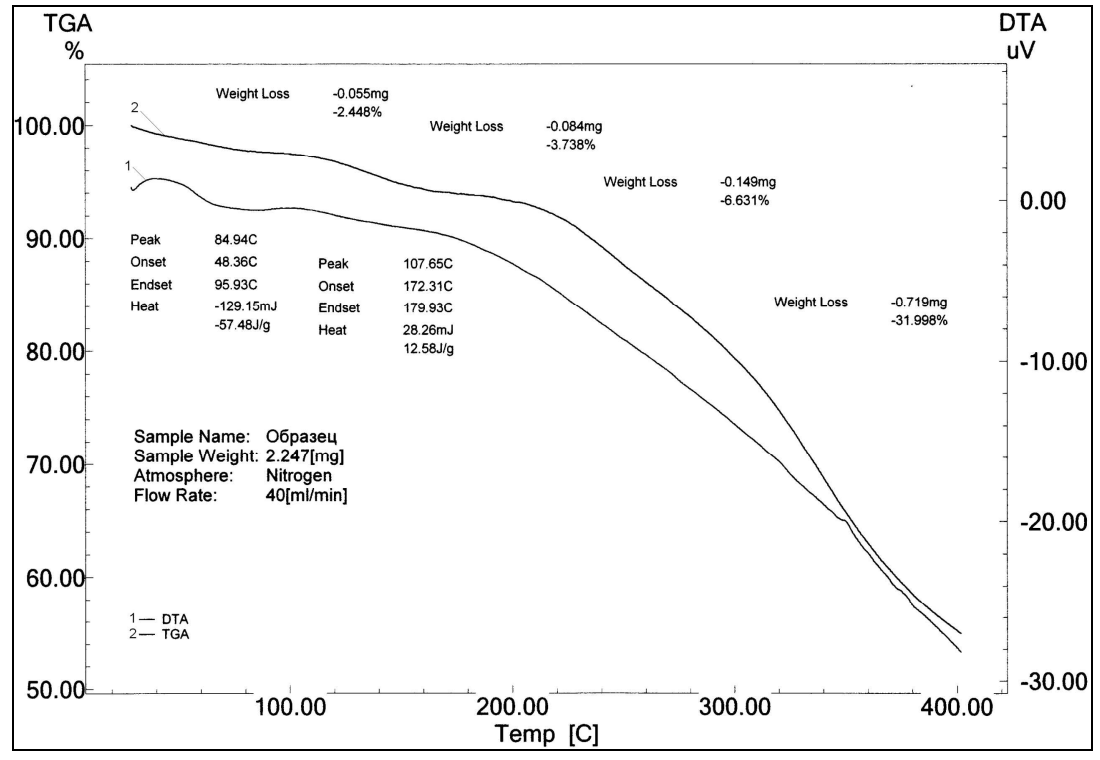

Рис. 2. ДСК (1) и ТГА (2) для АЛ 


\section{Bbыводbl}

Методом гидротермальной деполимеризации гидротропного лигнина, полученного из лигноцеллюлозного материала (Miscanthus sinensis Andersson), удалось получить две модифицированные формы лигнина. Одна из них растворяется во многих органических растворителях (органосолв) и имеет температуру размягчения $48-98{ }^{\circ} \mathrm{C}$, а другая форма практически нерастворима в органических растворителях и не подвергается размягчению даже при высоких температурах.

\section{Электронный дополнительный материал}

В электронном приложении к статье приведены ЯМР-спектры ацетонлигнина, гидротропного лигнина и нерастворимого остатка в ацетоне.

Выражаем благодарность профессору, доктору химических наук Н.Г. Базарновой за помощь, оказанную при определении метоксильных групп в АЛ, ГЛ и НОА.

\section{Сиисок литературы}

1. Митрофанов Р.Ю., Будаева В.В., Денисова М.Н., Сакович Г.В. Гидротропный метод получения целлюлозы из мискантуса // Химия растительного сырья. 2011. №1. С. 25-32.

2. Jones M.B., Walsh M. Miscanthus: For Energy and Fibre. London: Published by James \& James (Science Publishers) Ltd. 2001. 192 p.

3. Shumny V.K. Veprev S.G., Nechiporenko N.N., Goryachkovskaya T.N., Slynko N.M., Kolchanov N.A., Peltek S.E. A new form of Miscanthus (Chinese silver grass, Miscanthus sinensis -Andersson) as a promising source of cellulosic biomass // Advances in Bioscience and Biotechnology. 2010. Vol. 1. Pp. 167-170.

4. Судакова И.Г., Кузнецов Б.Н., Гарынцева Н.В., Королькова И.В. Состав и связующие свойства лигнинов, полученных окислительной делигнификацией древесины пихты, осины и березы в среде уксусной кислоты // Химия растительного сырья. 2010. № 3 С. 55-60.

5. Inone-Kauffmann E., Eisenreich N., Eckl W., Plitzko Y. Bio-composites based on a lignin matrix from high-pressure hydrolysis // Proceedings of the 23rd Annual Meeting of the Polymer Processing Society (PPS-23), Salvador, Brazil, May 28-31, 2007.

6. Inone-Kauffmann E., Eisenreich N., Eckl W., Sakai T., Kondo M., Saka S. Compounds based on lignin from HPH process // Proceedings of the 23rd Annual Meeting of the Polymer Processing Society (PPS-23), Salvador, Brazil, May 28-31, 2007.

7. Никитин В.М., Оболенская А.В., Щеголев В.П. Химия древесины и целлюлозы. М., 1978. 366 с.

8. Закис Г.Ф. Функциональный анализ лигнинов и их производных. Рига, 1987. С. 23-28.

9. Шумный В.К. Новая форма Мискантуса китайского (Веерника китайского Miscanthus sinensis Anders) как перспективный источник целлюлозосодержащего сырья // Информационный вестник ВОГиС. 2010. Т. 14 , №1. C. $122-126$.

10. Оболенская А.В., Ельницкая 3.П., Леонович А.А. Лабораторные работы по химии древесины и целлюлозы : учебное пособие для вузов. М., 1991. 320 с.

11. Полезная модель № 2518 (РФ). Качающийся автоклав с электрообогревом для проведения гетерогенных процессов / В.А. Куничан, Г.И. Севодина, В.П. Севодин, Ю.Н. Денисов, В.М. Буров.16.08.1996.

12. Villaverde J.J., Li J., Ek M., Ligero P., Vega A. Native Lignin Structure of Miscanthus x giganteus and Its Changes during Acetic and Formic Acid Fractionation // J. Agric.Food Chem. 2009. №57. Pp. 6262-6270.

13. Wang K., Bauer S., Sun R. C. Structural Transformation of Miscanthus x giganteus Lignin Fractionated under Mild Formosolv, Basic Organosolv, and Cellulolytic Enzyme Conditions // J. Agric.Food Chem. 2012. №60. Pp. 144-152.

Поступило в редакичию 5 марта 2012 г.

После переработки 25 октября 2013 г. 
Il'yasov S.G. , Cherkashin V.A., Sakovich G.V. DEPOLYMERIZATION OF LIGNIN BY HYDROTHERMAL METHOD

Institute for Problems of Chemical and Energetic Technologies, Siberian Branch of the Russian Academy of Sciences (IPCET SB RAS), ul. Socialisticheskaya, 1, Biysk 659322, (Russia), e-mail: admin@ipcet.ru

Two modified forms of lignin were obtained by the hydrothermal depolymerization of lignin derived from a lignocellulosic source (Miscanthus sinensis-Andersson). One of them is soluble in many organic solvents (organosolv) and has a softening point of 48 to $98^{\circ} \mathrm{C}$, and the other one is practically insoluble in organic solvents and is unsoftenable even at high temperatures.

Keywords: hydrotropic lignin, acetolignin, depolymerization, hydrothermal treatment, organosolv

\section{References}

1. Mitrofanov R.Iu., Budaeva V.V., Denisova M.N., Sakovich G.V. Khimiia rastitel'nogo syr'ia, 2011, no. 1, pp. $25-32$. (in Russ.).

2. Jones M.B., Walsh M. Miscanthus: For Energy and Fibre. London: Published by James \& James (Science Publishers) Ltd. 2001. 192 p.

3. Shumny V.K. Veprev S.G., Nechiporenko N.N., Goryachkovskaya T.N., Slynko N.M., Kolchanov N.A., Peltek S.E. Advances in Bioscience and Biotechnology, 2010, vol. 1, pp. 167-170.

4. Sudakova I.G., Kuznetsov B.N., Garyntseva N.V., Korol'kova I.V. Khimiia rastitel'nogo syr'ia, 2010, no. 3, pp. 55-60. (in Russ.).

5. Inone-Kauffmann E., Eisenreich N., Eckl W., Plitzko Y. Bio-composites based on a lignin matrix from high-pressure hydrolysis. Proceedings of the 23rd Annual Meeting of the Polymer Processing Society (PPS-23), Salvador, Brazil, May 28-31, 2007.

6. Inone-Kauffmann E., Eisenreich N., Eckl W., Sakai T., Kondo M., Saka S. Proceedings of the 23rd Annual Meeting of the Polymer Processing Society (PPS-23), Salvador, Brazil, May 28-31, 2007.

7. Nikitin V.M., Obolenskaia A.V., Shchegolev V.P. Khimiia drevesiny i tselliulozy. [Wood Chemistry and Pulp]. Moscow, 1978, 366 p. (in Russ.).

8. Zakis G.F. Funktsional'nyi analiz ligninov $i$ ikh proizvodnykh. [Functional analysis of lignins and their derivatives]. Riga, 1987, pp. 23-28. (in Russ.).

9. Shumnyi V.K. Informatsionnyi vestnik VOGiS, 2010, vol. 14, no. 1, pp. 122-126. (in Russ.).

10. Obolenskaia A.V., El'nitskaia Z.P., Leonovich A.A. Laboratornye raboty po khimii drevesiny $i$ tselliulozy. [Laboratory work on the chemistry of wood and cellulose.]. Moscow, 1991, 320 p. (in Russ.).

11. Utility model 2518 (RU). 16.08.1996.

12. Villaverde J.J., Li J., Ek M., Ligero P., Vega A. J. Agric.Food Chem., 2009, no. 57, pp. 6262-6270.

13. Wang K., Bauer S., Sun R.C. J. Agric.Food Chem., 2012, no. 60, pp. 144-152. 
